N. Anfimov, V. Anosov, I. Chirikov-Zorin*, D. Fedoseev, O. Gavrishchuk, N. Khovanskiy, Z. Krumshtein, R. Leitner ${ }^{1}$, G. Meshcheryakov, A. Nagaytsev, A. Olchevski, T. Rezinko, A. Selyunin, A. Rybnikov, Z. Sadygov, I. Savin, V. Tchalyshev, P. Zhmurin ${ }^{2}$

\title{
SHASHLYK EM CALORIMETER PROTOTYPE READ OUT BY MAPD WITH SUPERHIGH PIXEL DENSITY FOR COMPASS II
}

Presented at the 12th Pisa Meeting on Advanced Detectors "Frontier Detectors for Frontier Physics", May 20-26, 2012, La Biodola, Isola d'Elba, Italy

\footnotetext{
${ }^{1}$ Faculty of Mathematics and Physics of Charles University, Prague, Czech Republic

${ }^{2}$ Institute for Scintillation Materials, NAS of Ukraine, Ukraine

*E-mail: chirikov@nusun.jinr.ru
} 
Анфимов Н.В. и др.

Прототип ЭМ-калориметра типа «Шашлык»

со съемом информации MAPD

со сверхвысокой плотностью пикселей для COMPASS II

Разработан, создан и исследован высокогранулярный ЭМ-калориметр нового поколения типа «Шашлык» со съемом информации микропиксельными лавинными фотодиодами (MAPD) с прецизионной термостабилизацией, основанной на элементе Пельтье. В блоке фотодетектора использовались MAPD-3N со сверхвысокой плотностью пикселей $1,5 \cdot 10^{4} \mathrm{Mм}^{-2}$ и площадью $3 \times 3$ мм, изготовленные компанией Zecotek.

Работа выполнена в Лаборатории ядерных проблем им. В.П.Джелепова ОИЯИ.

Anfimov N. V. et al.

E13-2012-68

Shashlyk EM Calorimeter Prototype Read Out by MAPD

with Superhigh Pixel Density for COMPASS II

A new-generation high-granularity Shashlyk EM calorimeter read out by micropixel avalanche photodiodes (MAPD) with precision thermostabilization based on the Peltier element was designed, constructed and tested. MAPD-3N with a superhigh pixel density of $1.5 \cdot 10^{4} \mathrm{~mm}^{-2}$ and an area of $3 \times 3 \mathrm{~mm}$ manufactured by the Zecotek Company were used in the photodetector unit.

The investigation was performed at the Dzhelepov Laboratory of Nuclear Problems, JINR. 
A new high-granularity Shashlyk electromagnetic calorimeter ECAL0 covering larger photon angles was developed for the future measurements of generalized parton distributions at COMPASS II.

The design of the Shashlyk module is shown in Figs. 1 and 2. The module consists of a calorimeter and a photodetector unit. The mechanical design of the calorimeter is similar to the EM calorimeters described in $[1,2]$.

The Shashlyk EM calorimeter is a sandwich of alternative perforated stamped lead plates and injection-molded polystyrene-based scintillator (PS $+2 \%$ PTP $+0.05 \%$ POPOP) tiles read out by means of WLS fibers passing through the holes in the scintillator and lead. There are 109 sampling layers, each layer consisting of a 0.8 -mm-thick lead plate with dimensions of $119.8 \times 119.8 \mathrm{~mm}$ and nine 1.5 -mm-thick scintillator tiles with dimensions of $39.8 \times 39.8 \mathrm{~mm}$. The total length of the calorimeter is about $15 X_{0}$

The tiles have 16 holes equidistantly arranged in a $4 \times 4$ matrix with a $10.6 \mathrm{~mm}$ spacing between the holes for WLS fibers and one hole in the centre for the

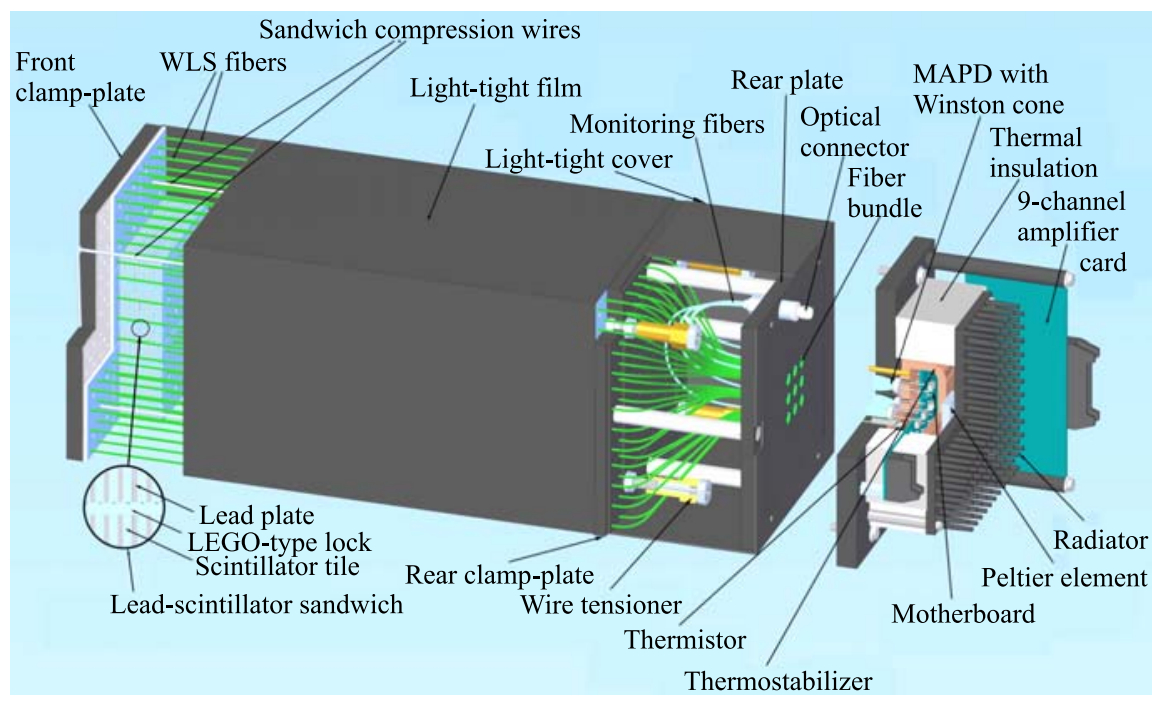

Fig. 1. The Shashlyk calorimeter module design 


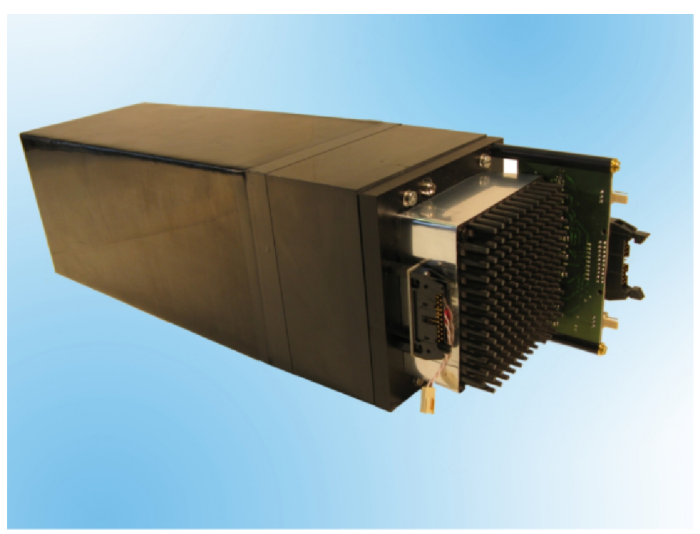

Fig. 2. View of the Shashlyk calorimeter module

compression wire. The edges of the tiles are painted white, and thus form nine light-isolated towers. Each tower is read out by means of 16 BCF-91A WLS fibers $1.2 \mathrm{~mm}$ in diameter. The fiber ends are shaped into a bundle $6 \mathrm{~mm}$ in diameter and glued inside the corresponding holes of the rear plate. Additionally, a clear fiber is inserted in each bundle used to transport light from the monitoring optical connector. Other ends of WLS fibers are mirrored by a special paint, namely Silver Shine No. M415001.

Each scintillator tile has four LEGO-type locks. These locks are used to simplify the module assembling process and maintain the alignment of the tiles and lead plates. The complete stack of lead-scintillator layers is held in compression by four stainless steel wires $1.2 \mathrm{~mm}$ in diameter between the front and rear plastic clamp-plates with the help of tensioners. Such a self-maintained design ensures high mechanical strength of the module due to static friction between the surfaces of the lead plates and scintillator tiles. The module is wrapped with a $0.1 \mathrm{~mm}$ black polyester film to make sure it is light-tight.

Since the ECAL0 calorimeter will be installed close to the magnet, the photodetector should be insensitive to the magnetic field, and a PMT cannot be used. Therefore, the micropixel avalanche photodiodes MAPD-3N [3] with a gain of $4 \cdot 10^{4}$, photon detection efficiency $(\mathrm{PDE}) \simeq 25 \%$ in the green region, a superhigh pixel density of $1.5 \cdot 10^{4} \mathrm{~mm}^{-2}$ and an area of $3 \times 3 \mathrm{~mm}$ manufactured by the Zecotek Company [4] are used in the photodetector unit (Fig. 1).

Because the fiber bundle is $6 \mathrm{~mm}$ in diameter while the sensitive area of MAPD-3N is square-shaped and $3 \times 3 \mathrm{~mm}$, the polystyrene Winston cone light guide ( $L=10.1 \mathrm{~mm}, D_{1}=7.2 \mathrm{~mm}, D_{2}=3.3 \mathrm{~mm}$ ) glued to the MAPD surface is used to increase light collection (Fig. 3). Measured light collection efficiency of the Winston cone is about $95 \%$. 


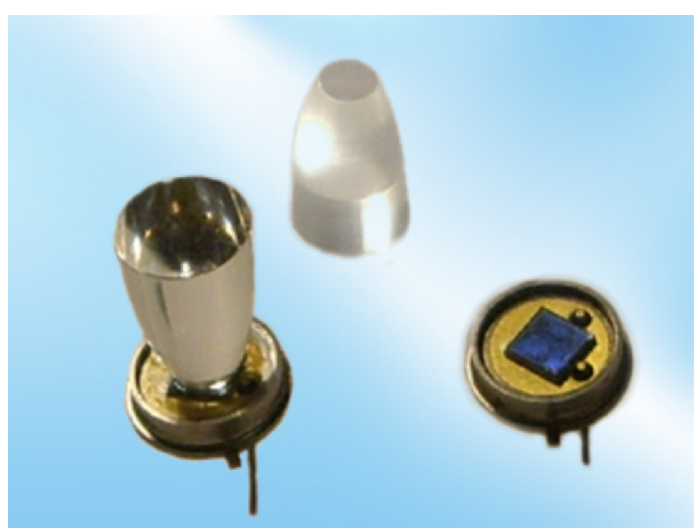

Fig. 3. View of MAPD with and without the Winston cone

The gain and PDE of MAPD significantly depend on the environmental temperature (a few percent per one degree). It is therefore necessary to stabilize the temperature of MAPD.

The thermostabilizer of the photodetector unit is based on the Peltier element $(15 \times 15 \mathrm{~mm})$ and is made of copper plates. The Peltier element is glued to the outside surface of the thermostabilizer by the heat-conducting glue (Fig. 4). The motherboard is installed in the thermostabilizer and has connectors for MAPD, a 9-channel amplifier card, power supply and an electronic temperature stabilization system. The thermal insulation of the thermostabilizer against ambient temperatures is made of cellular polythene. The side of the Peltier element that is being

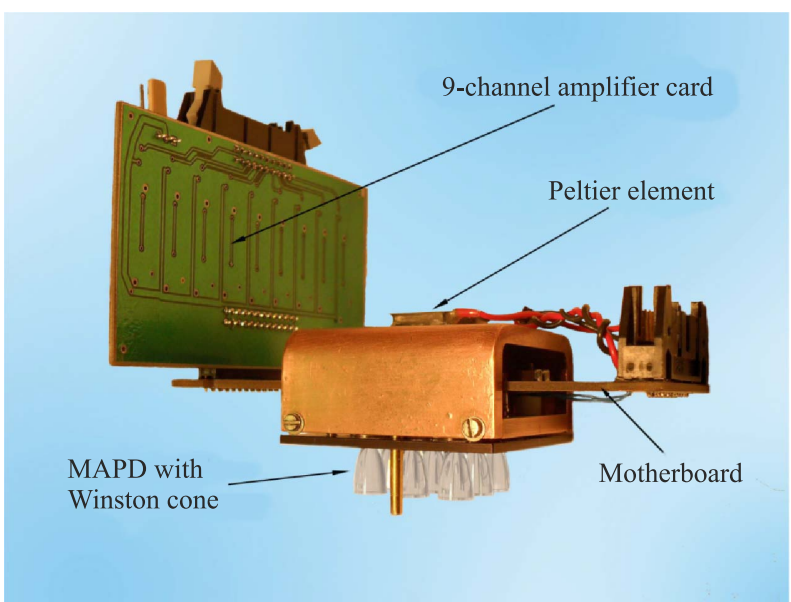

Fig. 4. View of the thermostabilizer with MAPD etc. 


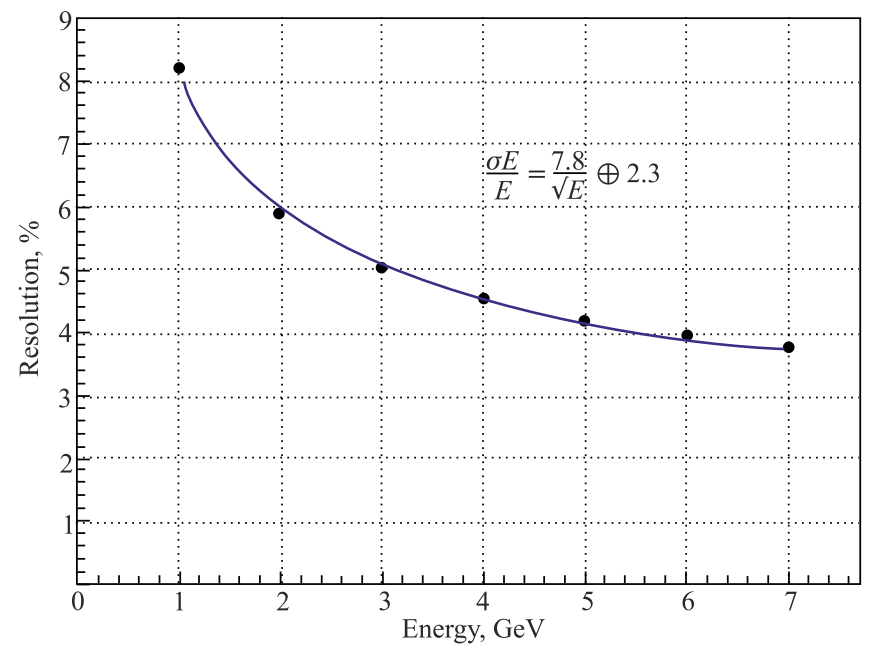

Fig. 5. Energy resolutions of the ECALO $3 \times 3$ module matrix read out by MAPD at $T=15^{\circ} \mathrm{C}$ versus the electron beam energy

heated up is cooled down by the radiator. The thermostabilizer at an ambient temperature of $25^{\circ} \mathrm{C}$ keeps the MAPD temperature at $15^{\circ} \mathrm{C}$ with an accuracy of $0.05^{\circ} \mathrm{C}$ at power about $1 \mathrm{~W}$.

Preliminary results of the first studies of the ECALO $3 \times 3$ module matrix at the T9 CERN PS test-beam facility are shown in Fig. 5.

\section{REFERENCES}

1. Atoian G. S. et al. // Nucl. Instr. Meth. A. 2008. V.584. P. 291.

2. Arefev A. V. et al. // Instr. Exp. Tech. 2008. V.51, No.4. P. 511.

3. Anfimov N. et al. // Nucl. Instr. Meth. A. 2010. V.617. P.78.

4. http://www.zecotek.com/ 


\section{Редактор С. В. Савиных}

Подписано в печать 4.09.2012.

Формат $60 \times 90 / 16$. Бумага офсетная. Печать офсетная.

Усл. печ. л. 0,6. Уч.-изд. л. 0,44. Тираж 265 экз. Заказ № 57750.

Издательский отдел Объединенного института ядерных исследований 141980 , г. Дубна, Московская обл., ул. Жолио-Кюри, 6.

E-mail: publish@jinr.ru www.jinr.ru/publish/ 